\title{
Pyrolysis of torrefied oil palm wastes for better biochar
}

\author{
Nurhayati Abdullah, Fauziah Sulaiman, Aminu Aliyu Safana*
}

School of Physics, Universiti Sains Malaysia, 11800 USM Pulau Penang, Malaysia

*Corresponding author: basalihe2@gmail.com

\section{Article history}

Received 24 February 2017

Accepted 14 May 2017

\begin{abstract}
The objective of this research work is to investigate the effect of torrefaction on the pyrolysis product. Biomass materials such as empty fruit bunch (EFB), mesocarp fibre (MF) and palm shell (PKS) were torrefied and pyrolyzed. The experiment conditions were set to be respectively at $220{ }^{\circ} \mathrm{C}$ for temperature, $10^{\circ} \mathrm{C} / \mathrm{min}$ of heating rate and 30 minutes holding time for torrefaction and at $650{ }^{\circ} \mathrm{C}$ of temperature, $20^{\circ} \mathrm{C} / \mathrm{min}$ heating rate and 2 hours holding time for pyrolysis. Nitrogen flow rate of $2 \mathrm{~L} / \mathrm{min}$ was maintained for both experiments. The torrefied biomass contains high carbon content and low oxygen content than the raw biomass. Also, the biochar derived from torrefied biomass have high fixed carbon content than the biochar derived from untorrefied biomass. The maximum higher heating value $(\mathrm{HHV})$ of about $31.2 \mathrm{MJkg}^{-1}$ is obtained in the biochar derived from the torrefied shell. Though, all the biomass materials used in this research have exhibited a positive outcome after being torrefied and pyrolyzed. It is clear from scanning electron microscopy (SEM) images that the biochar (b) and (d) derived from torrefied biomass could be better in the application of soil amendment and water retention due to a large number of holes. Therefore, it can be concluded that pyrolysis of torrefied biomass improved the quality of biochar than the biochar obtained from untorrefied biomass
\end{abstract}

Keywords: Torrefaction, pyrolysis, biochar

\section{INTRODUCTION}

Biomass energy sources are described as lignocellulosic substance generated from living organic matter like agricultural wastes and wood. However, non-lignocellulosic substances such as animal and municipal solid wastes (MSWs) are recognized as biomass. The main components of lignocellulosic biomass are cellulose, hemicelluloses, and lignin. Biomass energy has an advantage of being converted into three products (solid, liquid and gaseous). It has a potentiality for sustaining future power generation because it is obtainable and can develop quickly on fertile and unfertile soil (Kambo and Dutta, 2015). Furthermore, biomass energy shows a climate free characteristic in its production and utilization. Because limited quantity of $\mathrm{CO}_{2}$ is released into the environment. Although during application of biomass $\mathrm{CO}_{2}$ is released, it is immediately captured and stored in the biomass resource via photosynthesis and is extracted from the atmosphere which means a climate free carbon cycle of $\mathrm{CO}_{2}$. Malaysia is next to Indonesia in the global oil palm manufacturing; there are over 368 palm mills nationwide. It has been declared that in the year 2012 there were profitable oil palm wastes (dry weight) of about 83 million tonnes in Malaysia. And, it will eventually ascend to 100 million tonnes in few years to come (2020). In 2009, the oil palm wastes rendered in Malaysia were 7.0 million tonnes of EFB, 11.6 million tonnes of PKS and MF, 44.8 million tonnes of fronds and 13.9 million tonnes of trunks. However, eminent expected utility of these wastes is assumed to circumscribed (Awalludin et al., 2015). Between the oil palm biomass, mesocarp fibre contains a high calorific value in comparison with palm shell and EFB (Idris et al., 2012).

However, there are some properties of biomass that are not favorable in its applications they include high oxygen content, a low calorific value, a hydrophilic nature and high moisture content. The high oxygen and moisture contents in biomass led to the departure of smoke while burning. Other problems colligated with biomass are its tough and fibrous structure and its complex composition that makes development management hard. The most fundamental problem in using biomass as fuel is the transformation processes. There are supposed to be conventional means for transforming biomass into better and qualitative fuels in such a way that they can compete with fossil fuels (Vander et al., 2011). Medic et al. (2012) reported that low bulk density, degradation during storage and low energy density are also important factors affecting utilization of raw lignocellulosic biomass as a cellulose feedstock. Nevertheless, there are many ways through which biomass combustion characteristics can be improved; they include thermochemical pretreatment and biological methods. Though, thermochemical pretreatment is considered over biological methods. Torrefaction, pyrolysis and gasification are among the thermochemical processes (Kambo and Dutta, 2015).

Torrefaction is described as mild pyrolysis. It is carried out at a low heating rate and a temperature between 200 to $300{ }^{\circ} \mathrm{C}$ under an oxygen-free environment (Medic et al., 2012; Basu et al., 2014). The residence time usually last from 60 minutes to hours (Basu et al., 2014). The degradation of hemicelluloses during torrefaction produced several permanent gasses and condensates with high oxygen content. And, the final solid product (torrefied biomass) will be more of cellulose and lignin, as results the brittleness, hydrophobicity, microbial degradation resistance and energy density of torrefied biomass improved.

Therefore, torrefaction as thermochemical method could have a positive consequence on pyrolysis, gasification, and co-firing units operation by reducing power usage and cost for biomass grinding, eliminating compounds accountable for the high acidity of pyrolysis oil, and by escalating the consistency of biomass (Medic et al., 2012). The circumstances of fuel processing between torrefaction and 
pyrolysis are related however the temperatures range of pyrolysis is from 350 to $650{ }^{\circ} \mathrm{C}$ (Chen et al., 2011).

Pyrolysis conversion process is one of the prominent methods through which biomass are converted into three major by-products namely solid char, bio-oil, and gasses (Sukiran et al., 2009; Abnisa et al., 2013). Biochar is produced during the pyrolysis of biomass materials. The biomass is heated in the absence of oxygen at a temperature range of 300 to $1000{ }^{\circ} \mathrm{C}$. Biochar is described as charred organic matter, which can be used to improve the soil quality through sequestering carbon in the soils and also reduces greenhouse gas (GHG) emission. It is a steady carbon compound that can stay on the ground for over hundreds of years (Sulaiman et al., 2011; Abdullah and Sulaiman, 2013). This research is intended to use torrefaction to improve the quality of biochar via torrefaction pretreatment. The primary objective of this study is to investigate the effect of torrefaction on pyrolysis product.

\section{EXPERIMENTAL}

\section{Materials}

Mesocarp fibre, shell, and EFB were obtained from Oil Palm Industry located at Nibong Tebal, Pulau Pinang, Malaysia. The oil palm wastes received were relatively in a dry condition, yet they were dried for 24 hours at $105{ }^{\circ} \mathrm{C}$ in the oven to eliminate moisture. EFB sample was cut into small sizes of about $2-5 \mathrm{~cm}$ length.

\section{Sample Analysis}

Proximate analysis was carried out by ASTM E871 for moisture content, ASTM E872 for volatile matter and ASTM E1755-01 for ash content. Whereby, the difference determined fixed carbon. Elemental analysis was carried out to determine the fundamental elements such as carbon, hydrogen, nitrogen and sulphur, while oxygen was determined from the difference. It was conducted by Perkin Elmer 2400 analyzer, 2- $2.8 \mathrm{mg}$ of palm wastes was used to measure the percentage weight of each element present. The higher heating value (HHV) was determined using a bomb calorimeter system IKA C 200, oxygen station C248 with an empty water hose. For each test run, 0.5 to $0.8 \mathrm{~g}$ of the sample was measured and placed in the crucible joined to the thread from the ignition wire, closed and oxygen gas was pumped. However, the lower heating value (LHV) was calculated using HHV and hydrogen content measured as shown in Eq. (1) (Adisak Pattiya, 2006). LHV is important than HHV, attributable to the fact that LHV does not have any input from the latent heat of the vapor (Uemura et al., 2011).

$$
L H V_{d r y}\left(M J \mathrm{~kg}^{-1}\right)=H H V_{d r y}-2.442\left(\frac{8.936 H}{100}\right)
$$

where $\mathrm{H}$ is the weight percentage of hydrogen on a dry basis.

Thermogravimetric analysis (TGA) was performed with a digital Perkin-Elmer Pyris1 thermogravimetric analyzer. It was conducted under nitrogen with a heating rate of $10^{\circ} \mathrm{C} / \mathrm{min}, 100 \mathrm{ml} / \mathrm{min}$ nitrogen flow and on the sample size of $250-355 \mu \mathrm{m}$ with the purpose of estimating the qualitative composition of the sample, in fastidious with regards to hemicellulose, cellulose, lignin and their thermal degradation behavior. The analyses conducted on raw and torrefied biomass are presented in Table1.

\section{Torrefaction and Pyrolysis Experiments}

The torrefaction experiment was conducted using a stainless steel reactor of $250 \mathrm{~mm}$ length and $120 \mathrm{~mm}$ internal diameter. The biomass in the reactor was heated to a temperature of $220{ }^{\circ} \mathrm{C}$ at a constant heating rate of $10{ }^{\circ} \mathrm{C} / \mathrm{min}$ for $30 \mathrm{~min}$. Nitrogen was used as reaction gas it flowed at $2 \mathrm{~L} / \mathrm{min}$ throughout the experiment. After the experiment, the reactor was allowed to cool down, and the torrefied biomass was collected, weighted and stored before the pyrolysis.

The pyrolysis experiment was carried out using a stainless steel pyrolyzer of $150 \mathrm{~mm}$ length and $70 \mathrm{~mm}$ internal diameter. A prescribed quantity of torrefied biomass was measured and placed inside the pyrolyzer. During the experiment $2 \mathrm{~L} / \mathrm{min}$ of nitrogen was circulated throughout the pyrolyzer and heated to $650^{\circ} \mathrm{C}$ at a constant heating rate of $20^{\circ} \mathrm{C} / \mathrm{min}$, and retention time of 2 hours. The pyrolyzer temperature was monitored using a K-type thermocouple. Biochar residue and biooil were collected, measured and stored, while non-condensable gas was calculated from the difference.

\section{Scanning Electron Microscopy (SEM)}

In this work, the morphology of biochar was characterized using a SEM. It was conducted using EVO/MA10 model SEM which was controlled at a $20 \mathrm{kV}$ accelerated voltage and magnification of $500 \mathrm{mag}$. Before the SEM, the sample was sieved to a uniform size of about 150 $\mu \mathrm{m}$ and dried in an oven for 24 hours at $105{ }^{\circ} \mathrm{C}$. There was no coating before SEM analysis.

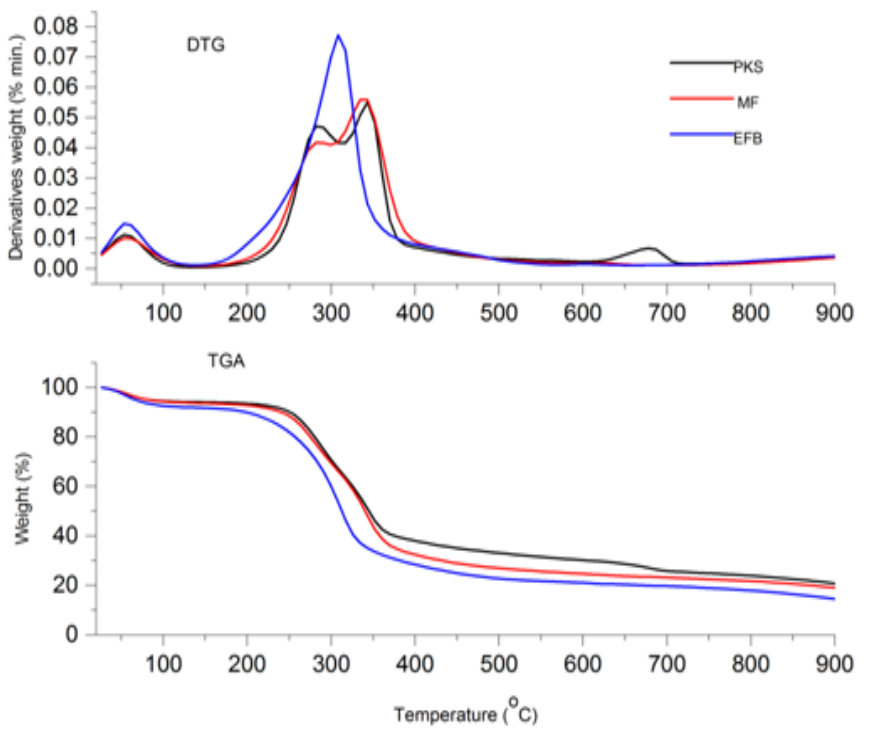

Fig. 1 Thermal analysis of raw samples TGA and DTG curves.

\section{RESULTS AND DISCUSSION}

\section{Thermal and lignocellulosic analysis}

The TGA and DTG of raw samples are shown in Fig.1. It displays first small peak corresponds to the evaporation of moisture and the early weight loss at a temperature lower than $150{ }^{\circ} \mathrm{C}$ for all the raw palm biomass. Hemicelluloses degradation commences at a temperature around $270{ }^{\circ} \mathrm{C}$ for $\mathrm{EFB}, 290{ }^{\circ} \mathrm{C}$ for fibre and $300{ }^{\circ} \mathrm{C}$ for the shell, respectively. It was reported by Sulaiman and Abdullah, (2011) that DTG curves for shell and fibre attain separate peaks for hemicellulose at around $300{ }^{\circ} \mathrm{C}$ and cellulose above $300{ }^{\circ} \mathrm{C}$. In this study, the peak around $310^{\circ} \mathrm{C}$ and $360{ }^{\circ} \mathrm{C}$ corresponds to the degradation of cellulose for EFB, and fibre and shell, respectively. Though the breakdown of cellulose and hemicelluloses is a constant progression, the weight loss of these constituents sustained nearly throughout the heating period.

Although, the maximum decline speeds of celluloses were observed between 300 to $360{ }^{\circ} \mathrm{C}$ and hemicelluloses were between 270 to $300{ }^{\circ} \mathrm{C}$ for all the palm oil wastes studied. The degradation of lignin was seen at $650{ }^{\circ} \mathrm{C}$, whereby shell showed high resistant to temperature due to the high lignin content. The total weight loss between 100 to 450 ${ }^{\circ} \mathrm{C}$ is $78.6,75.71 \%$ and $98.5 \%$ for EFB, fibre, and shell, respectively.

The lignocellulosic analysis in Table 1 showed that the raw materials contain cellulose, hemicelluloses, and lignin between (24 $43 \mathrm{wt} \%),(25-38 \mathrm{wt} \%)$ and $(20-50 \mathrm{wt} \%)$, respectively. EFB was found to contain a higher percentage of cellulose whereas, fibre has a higher content of hemicellulose, and higher lignin content was found in palm shell.

\section{Proximate, elemental analysis and calorific value}

The results from the proximate, elemental and calorific value analysis of raw and torrefied biomass are given in Tables 1. The moisture, ash and volatile matter contents of the raw biomass decreased after torrefaction. Whereas, fixed carbon and carbon content increased in the torrefied biomass. The range of carbon and oxygen contents were 
found to be respectively 42 to $48 \mathrm{wt} \%$ and 44 to $50 \mathrm{wt} \%$ for raw biomass and 43 to $52 \mathrm{wt} \%$ and 40 to $49 \mathrm{wt} \%$ for torrefied biomass. The sulphur content in raw biomass was found to be low between 0.08 to $0.12 \mathrm{wt} \%$. Thus it was not measured in torrefied and biochar. However, the average chemical composition of raw and torrefied biomass was obtained from a chemical composition as EFB, fibre, and shell as $\mathrm{CH}_{1.74} \mathrm{~N}_{0.01} \mathrm{O}_{0.90}$ and $\mathrm{CH}_{1.58} \mathrm{~N}_{0.01} \mathrm{O}_{0.85}$ for $\mathrm{EFB}, \mathrm{CH} 1 .{ }_{34} \mathrm{~N}_{0.01} \mathrm{O}_{0.76}$ and $\mathrm{CH}_{1.32} \mathrm{~N}_{0.02} \mathrm{O}_{0.72}$ for fibre, and $\mathrm{CH}_{1.42} \mathrm{~N}_{0.01} \mathrm{O}_{0.68}$ and $\mathrm{CH}_{1.4} \mathrm{~N}_{0.01} \mathrm{O}_{0.59}$ for the shell, respectively.

The HHV of raw biomass were observed to have increased in torrefied biomass by $2 \%$ for EFB, $1 \%$ for fibre and $<1 \%$ for the shell. It was discovered that the HHV of raw and torrefied biomass were in the range of $17-21 \mathrm{MJkg}^{-1}$. Mesocarp fibre was found to contain the highest $\mathrm{HHV}$ in the raw biomass and after torrefaction. However, the effect of torrefaction was observed higher in EFB, may be due to high moisture and high volatile matter content in the raw sample which was drastically reduced after torrefaction and consequently increased the calorific value.

Vander et al. (2011) reported that one of the significant benefits of torrefaction is that energy densification factor of 1.3 can be achieved. The energy density of torrefied biomass is greater than raw biomass. For instance, $70 \%$ of the mass content for woody biomass torrefaction is maintained as a solid product, and the other $30 \%$ is transformed into torrefaction gas. The solid product contains $90 \%$ of energy content while the remaining $10 \%$ is with the torrefaction gas. Also, torrefied wood has greater combustion rate and generates very low smoke than wood. Moreover, torrefied briquettes were water resistant, and torrefaction surfaced to be an excellent system for improvement briquettes.

\section{Biochar characterization}

The characteristics of biochar produced at $650{ }^{\circ} \mathrm{C}$ from torrefied and untorrefied biomass are presented in Table 2. The proximate and elemental characteristics determined the quality of biochar for industrial and domestic applications (Angin, 2013). The ash and volatile matter contents of the biochar obtained from torrefied biomass were lower than biochar derived from untorrefied biomass. Fixed carbon and carbon contents were higher in the biochar derived from torrefied biomass. The biochar derived from torrefied shell had a

low content of ash and volatile matter contents of $3.6 \mathrm{wt} \%$ and $10.7 \mathrm{wt} \%$, respectively. It also contains the highest fixed carbon content of $76.6 \mathrm{wt} \%$ in comparison to other biochar. The carbon, oxygen and nitrogen contents were between 66 to $83 \mathrm{wt} \%, 9$ to $29 \mathrm{wt} \%$ and 0.49 to $1.12 \mathrm{wt} \%$, for all biochars produced.The HHV of biochars is shown in Table 2. The calorific values of biochars were almost the same. The $\mathrm{HHV}$ of the biochar from untorrefied and torrefied biomass were found to be respectively 26.7 and $28.2 \mathrm{MJkg}^{-1}$ for $\mathrm{EFB}, 28.4$ and $29.9 \mathrm{MJkg}^{-1}$ for fibre, and 30.3 and $31.2 \mathrm{MJkg}^{-1}$ for palm shell.
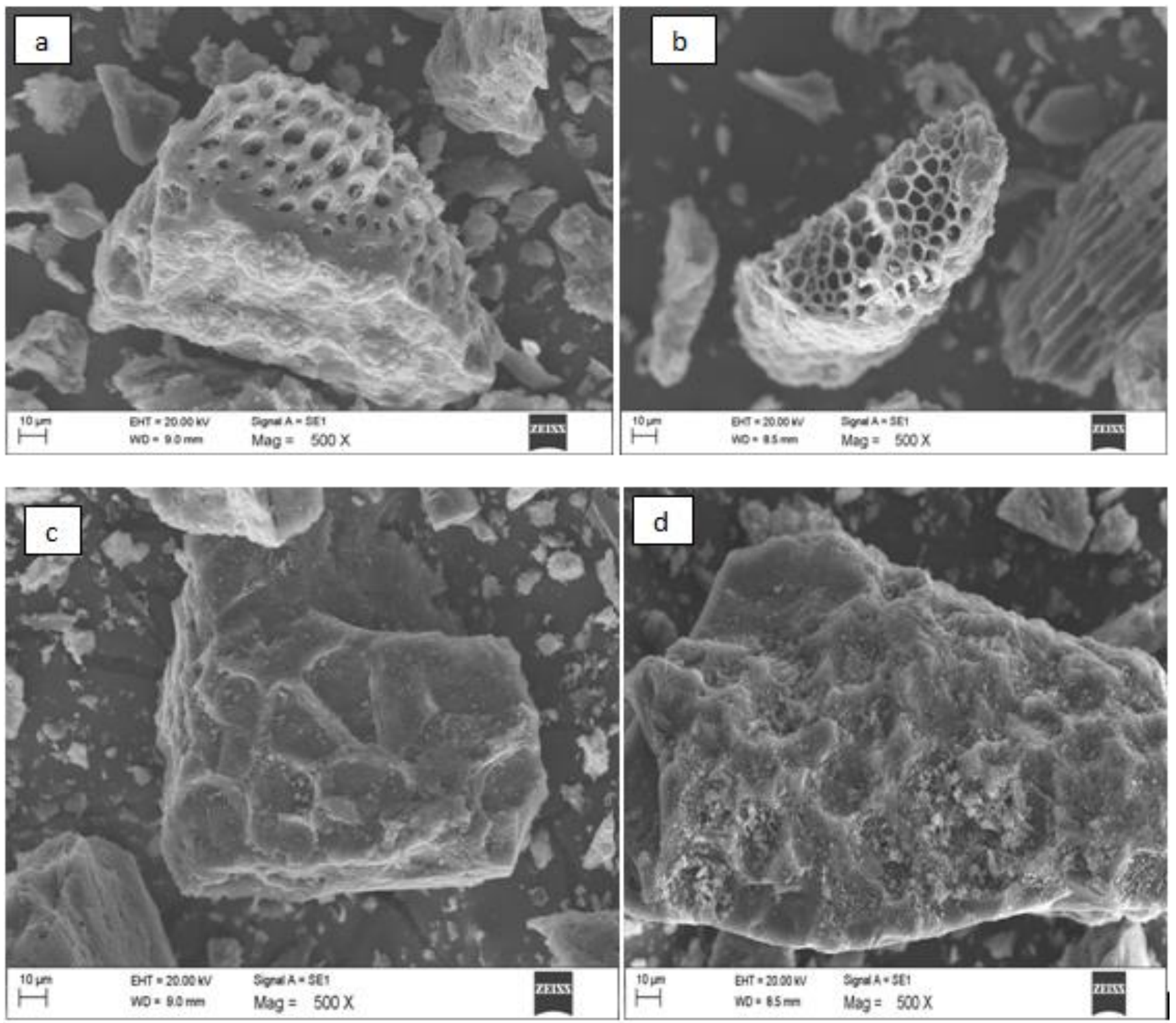

Fig. 2 SEM images of (a) Untorrefied MF biochar (b) torrefied MF biochar (c) untorrefied PKS biochar and (d) torrefied PKS biochar. 
Table 1 Physical, chemical properties and calorific value of biomass.

\begin{tabular}{|c|c|c|c|c|c|c|}
\hline \multirow{2}{*}{$\begin{array}{l}\text { Biomass } \\
\text { Properties(wt\%) }\end{array}$} & \multicolumn{2}{|c|}{ EBF } & \multicolumn{2}{|c|}{ MF } & \multicolumn{2}{|c|}{ PKS } \\
\hline & Raw & $220^{\circ} \mathrm{C}$ & Raw & $220^{\circ} \mathrm{C}$ & Raw & $220^{\circ} \mathrm{C}$ \\
\hline Cellulose & 43.31 & ---- & 35.91 & ---- & 24.03 & ---- \\
\hline Hemicellulose & 36.29 & ---- & 38.00 & ---- & 25.21 & ---- \\
\hline Lignin & 20.40 & --- & 26.09 & --- & 50.76 & --- \\
\hline Moisture C. & 7.3 & 5.9 & 5.4 & 3.9 & 4.4 & 2.81 \\
\hline Volatile Matter & 80.2 & 73.6 & 76.6 & 70.8 & 75.09 & 71.9 \\
\hline Ash Content & 2.4 & 1.8 & 3.1 & 3.7 & 4.29 & 4.52 \\
\hline Fixed Carbon ${ }^{b}$ & 10.1 & 18.7 & 14.9 & 21.6 & 16.22 & 20.77 \\
\hline Carbon & 42.3 & 43.8 & 46.81 & 47.92 & 48.91 & 52.12 \\
\hline Hydrogen & 6.2 & 5.8 & 5.27 & 5.31 & 5.81 & 6.12 \\
\hline Nitrogen & 0.47 & 0.59 & 0.71 & 1.03 & 0.85 & 1.1 \\
\hline Sulphur & 0.09 & --- & 0.08 & --- & 0.12 & --- \\
\hline Oxygen ${ }^{b}$ & 50.94 & 49.81 & 47.13 & 45.74 & 44.31 & 40.66 \\
\hline $\mathrm{HHV}\left(\mathrm{MJkg}^{-1}\right)$ & 17.5 & 19.1 & 20.1 & 21.2 & 19.2 & 19.8 \\
\hline LHV $\left(\mathrm{MJkg}^{-1}\right)$ & 16.15 & 17.8 & 19.0 & 20.0 & 17.9 & 18.5 \\
\hline
\end{tabular}

Table 2 Characterization of Biochar derived from torrefied (treated) and untreated biomass.

\begin{tabular}{|c|c|c|c|c|c|c|}
\hline \multirow{2}{*}{$\begin{array}{l}\text { Biomass } \\
\text { Properties (wt\%) }\end{array}$} & \multicolumn{2}{|r|}{ EFB } & \multicolumn{2}{|c|}{ MF } & \multicolumn{2}{|c|}{ PKS } \\
\hline & Treated & Untreated & Treated & Untreated & Treated & Untreated \\
\hline $\begin{array}{l}\text { Moisture C. } \\
\text { Volatile M. }\end{array}$ & $\begin{array}{l}8.6 \\
42.2\end{array}$ & $\begin{array}{l}8.3 \\
43.8\end{array}$ & $\begin{array}{l}4.5 \\
12.13\end{array}$ & $\begin{array}{l}6.7 \\
16.5\end{array}$ & $\begin{array}{l}3.6 \\
10.7\end{array}$ & $\begin{array}{l}5.1 \\
11.3\end{array}$ \\
\hline Ash Content & 12.5 & 12.2 & 9.7 & 10.9 & 9.1 & 12.3 \\
\hline Fixed $C^{b}$ & 36.7 & 35.7 & 73.67 & 65.9 & 76.6 & 71.3 \\
\hline $\begin{array}{l}\text { Carbon } \\
\text { Hydrogen } \\
\text { Nitrogen } \\
\text { Oxygen } \\
\left.\text { HHV }^{\text {H }} \text { Mkg }^{-1}\right)\end{array}$ & $\begin{array}{l}67.2 \\
3.21 \\
1.12 \\
28.47 \\
28.2\end{array}$ & $\begin{array}{l}66.5 \\
3.31 \\
1.10 \\
29.09 \\
26.7\end{array}$ & $\begin{array}{l}75.2 \\
4.2 \\
0.49 \\
20.11 \\
29.9\end{array}$ & $\begin{array}{l}74.3 \\
3.61 \\
0.52 \\
21.57 \\
28.4\end{array}$ & $\begin{array}{l}81.2 \\
5.51 \\
0.92 \\
12.37 \\
31.2\end{array}$ & $\begin{array}{l}83.6 \\
6.22 \\
1.12 \\
9.06 \\
30.4\end{array}$ \\
\hline
\end{tabular}

${ }^{\mathrm{b} B y}$ difference.

\section{Scanning electron microscopy}

The structure of holes and shapes generated through pyrolysis on the surface of biochar can be clearly observed on SEM images, indicating an assorted of shapes in the pores. However, the production of volatile matter during pyrolysis are considered responsible for the new structure, which generated additional adsorption sites for ions, space for nutrients and water holding in biochar (Moralı and Şensöz, 2015). Table 1 and 2 displayed the volatility contents of raw, torrefied biomass and biochar. The volatile matter contents of the raw biomass studied were reduced in the torrefied biomass. During the pyrolysis of untorrefied biomass, the volatile matter content produced was found to be respectively $60.1 \mathrm{wt} \%$ for fibre and $63.79 \mathrm{wt} \%$ for the shell. For the pyrolysis of torrefied biomass, the volatile matter released was 58.67 $\mathrm{wt} \%$ for fibre and $61.2 \mathrm{wt} \%$ of the shell, respectively. It implies that high quantity of volatile matter is produced during the pyrolysis of untorrefied biomass. It can also be seen clearly from the SEM images in Fig.2, that the structure and holes of (a) and (c) images for biochar obtained from untorrefied biomass were few and scattered, and with an average size of the holes are between 10 to $14 \mu \mathrm{m}$. However, torrefied biochar, the structure, and holes of (b) images were found to be uniform and with an average size of $4-5 \mu \mathrm{m}$ for fibre. The large hole in fibre may be due to the high content of volatile matter in the raw material (Table 1) which were produced and released during pyrolysis. For the shell, the structure and holes are not uniform as shown in image (d), the average size of holes are between and $12-13 \mu \mathrm{m}$. It could be associated with the high-temperature resistance of shell due to it's high content of lignin (Table 1). It has been reported that the porous structure of biochar can describe its influence on soil water retention and adsorption ability. Biochar produced at low temperature are, however, hydrophobic and this might reduce the ability to retain water. Though biochar at low temperature is stronger than high-temperature products; it is brittle and prone to abrade into fine portions once incorporated (Sohi et al., 2009).

\section{CONCLUSION}

The interest in the applications of biochar is increasing globally. Pyrolysis is one of the most promising methods for generating biochar from biomass. Torrefaction has been widely used to improve the quality of biomass by removing moisture and oxygen contents among others. Whereby, the torrefied biomass became denser, hydrophobic, brittle and high calorific value than raw biomass. This research attempted to use torrefaction beyond the universal application.

Biomass materials such as EFB, mesocarp fibre, and palm shell were torrefied and pyrolyzed. The experimental results showed that all the biochars from torrefied biomass possess high fixed carbon content than the biochar from untorrefied biomass. It was found that the moisture, ash and volatile matter contents of the raw biomass decreased after torrefaction. Whereas, fixed carbon and carbon content increased in the torrefied biomass.

The ash and volatile matter contents of the biochar obtained from torrefied biomass were lower than those obtained from biochar of untorrefied biomass. Fixed carbon and carbon contents were higher in the biochar derived from torrefied biomass. The biochar from torrefied shell had a low content of ash, and volatile matter contents $3.6 \mathrm{wt} \%$ and $10.7 \mathrm{wt} \%$, respectively. However, the effect of torrefaction was observed higher in EFB, may be due to high moisture and high volatile matter content in the raw sample which was drastically reduced after torrefaction and consequently increases the calorific value.

In all the biomass studied, the palm shell exhibit high calorific value in the biochar product. Therefore, the shell can be described as a better sample which can undergo torrefaction and pyrolysis than fibre and EFB. It can be concluded from SEM images that the biochar (b) and (d) derived from torrefied biomass could be better in the application of soil amendment and water retention due to a large number of uniform holes. Despite the fact that biochar (a) and (c) derived from untorrefied biomass had larger holes size, but they are described as hydrophobic in nature. 


\section{ACKNOWLEDGEMENT}

The authors wish to express their gratitude to the Universiti Sains Malaysia for financing this research through grants RUI [1001/PFIZIK/814250], [1001/PFIZIK/814228] and FRGS [203/PFIZIK/6711410]. My thanks go to my institution in Nigeria (Federal University Dutse, Nigeria) for giving me the opportunity to study at Universiti Sains Malaysia.

\section{REFERENCES}

Abdullah, N., Sulaiman, F. 2013. The oil palm wastes in Malaysia. In Matovic, M. D. (Ed.). Biomass Now-Sustainable Growth and Use (pp. 978 - 953) Crotia: InTech. Retrieved from: https://www.intechopen.com/books/ biomass-now-sustainable-growth-and-use/the-oil-palm-wastes-in-malaysia.

Abnisa, F., Arami-Niya, A., Daud, W. M. A. W., Sahu, J. N. 2013 Characterization of bio-oil and bio-char from pyrolysis of palm oil wastes BioEnergy Research, 6, 830-840.

Adisak P., James O. T., Anthony, V. B. 2006. Fast pyrolysis of agricultura residues from cassava plantation for bio-oil production. 2nd Join International Conference on Sustainable Energy and Environment. 21-23 November 2006. Bangkok, Thailand.

Angin, D. 2013. Effect of pyrolysis temperature and heating rate on biochar obtained from pyrolysis of safflower seed press cake. Bioresource Technology, 128, 593-597.

Awalludin, M. F., Sulaiman, O., Hashim, R. and Nadhari, W. N. A. W. 2015 An overview of the oil palm industry in Malaysia and its waste utilization through thermochemical conversion, specifically via liquefaction. Renewable and Sustainable Energy Reviews, 50, 1469-1484.

Basu, P., Sadhukhan, A. K., Gupta, P., Rao, S., Dhungana, A., Acharya, B. 2014 An experimental and theoretical investigation on torrefaction of a large wet wood particle. Bioresource Technology 159, 215-222.
Chen, W.-H., Hsu, H.-C., Lu, K.-M., Lee, W.-J., Lin, T.-C. 2011. Thermal pretreatment of wood (Lauan) block by torrefaction and its influence on the properties of the biomass. Energy, 36, 3012-3021.

Idris, S. S., Rahman, N. A., Ismail, K. 2012. Combustion characteristics of Malaysian oil palm biomass, sub-bituminous coal and their respective blends via thermogravimetric analysis (TGA). Bioresource Technology, 123, 581591.

Kambo, H. S., Dutta, A. 2015. A comparative review of biochar and hydrochar regarding production, physico-chemical properties, and applications. Renewable and Sustainable Energy Reviews, 45, 359-378.

Medic, D., Darr, M., Shah, A., Potter, B., Zimmerman, J. 2012. Effects of torrefaction process parameters on biomass feedstock upgrading. Fuel, 91, 147-154.

Morali, U., Şensöz, S. 2015. Pyrolysis of hornbeam shell (Carpinus betulus L.) in a fixed bed reactor: Characterization of bio-oil and bio-char. Fuel, 150, 672-678.

Sohi, S., Lopez-Capel, E., Krull, E., Bol, R. 2009. Biochar, climate change, and soil. A review to guide future research. Commonwealth Scientific and Industrial Reseach Organization Land and Water Science Report 05/09. CSIRO, Australia. Retrieved from website: www.csiro.au.

Sukiran, M. A., Chin, C. M., Bakar, N. K. A. 2009. Bio-oils from pyrolysis of oil palm empty fruit bunches. American Journal of Applied Sciences, 6, 869875.

Sulaiman, F., Abdullah, N., Gerhauser, H., Shariff, A. 2011. An outlook of Malaysian energy, oil palm industry and its utilization of wastes as useful resources. Biomass and Bioenergy, 35, 3775-3786.

Uemura, Y., Omar, W. N., Tsutsui, T., Yusup, S. B. 2011. Torrefaction of oil palm wastes. Fuel, 90, 2585-2591.

Van Der Stelt, M. J. C., Gerhauser, H., Kiel, J. H. A., Ptasinski, K. J. 2011 Biomass upgrading by torrefaction for the production of biofuels: A review. Biomass and Bioenergy, 35, 3748-3762. 